University of Wollongong

Research Online

Faculty of Social Sciences - Papers (Archive) Faculty of Arts, Social Sciences \& Humanities

$1-1-2018$

Towards sustainable technology-enhanced innovation in higher education: Advancing learning design by understanding and supporting teacher design practice

Sue Bennett

University of Wollongong, sbennett@uow.edu.au

Lori Lockyer

University of Technology, Sydney, lori.lockyer@gmail.com

Shirley Agostinho

University of Wollongong, shirleya@uow.edu.au

Follow this and additional works at: https://ro.uow.edu.au/sspapers

Part of the Education Commons, and the Social and Behavioral Sciences Commons

Research Online is the open access institutional repository for the University of Wollongong. For further information contact the UOW Library: research-pubs@uow.edu.au 


\title{
Towards sustainable technology-enhanced innovation in higher education: Advancing learning design by understanding and supporting teacher design practice
}

\author{
Abstract \\ Improving teacher design promises to be a scalable, sustainable approach to building capacity amongst a \\ workforce faced with complex and evolving drivers of change in higher education worldwide. While \\ design has long been recognised as a routine part of teaching, there has been renewed interest in \\ supporting and understanding the design work that teachers do to foster innovation, particularly in \\ technology-enhanced learning, at institutional scale by influencing teachers' practices. Re-framing \\ teaching as design usefully emphasises the creative problem-solving needed to balance pedagogical, \\ logistical and technical considerations within specific educational contexts, tailored to learners' needs. \\ There is potential for this re-framing to build on and advance work in "learning design" and "design for \\ learning" that has generated a wide range of practical supports and tools. In this article, we explore, \\ problematise and conceptualise the notion of "teacher as designer" within the complexity of \\ contemporary higher education through a critical review of existing empirical and conceptual work \\ internationally. We offer insights into the current state of knowledge about teacher design in higher \\ education, highlight gaps and possibilities, offer a new conceptualisation drawing on practice theory and \\ set out propositions to provoke further debate about teacher design as a vehicle for sustainable \\ innovation in higher education.

\section{Keywords} \\ design, understanding, supporting, teacher, practice, innovation, higher, technology-enhanced, advancing, \\ sustainable, towards, education:, learning \\ Disciplines \\ Education | Social and Behavioral Sciences

\section{Publication Details} \\ Bennett, S., Lockyer, L. \& Agostinho, S. (2018). Towards sustainable technology-enhanced innovation in \\ higher education: Advancing learning design by understanding and supporting teacher design practice. \\ British Journal of Educational Technology, 49 (6), 1014-1026.
}


Towards sustainable technology-enhanced innovation in higher education: Advancing learning design by understanding and supporting teacher design practice

Sue Bennett, University of Wollongong

Lori Lockyer, University of Technology Sydney

Shirley Agostinho, University of Wollongong

Correspondence

Professor Sue Bennett

School of Education, Faculty of Social Sciences

University of Wollongong

NSW 2522 Australia

$\mathrm{T}+61242215738$

F +61242213892

\section{Biographies}

Professor Sue Bennett is Head of the School of Education at the University of Wollongong. Sue's work investigates how people engage with technology in their everyday lives and in educational settings. Her aim is to develop a more holistic understanding of people's technology practices to inform research, practice and policy. She has been researching design thinking and learning design since 1999.

Professor Lori Lockyer is the Dean of the Graduate Research School at the University of Technology Sydney. She has been researching in the area of learning design for over a decade. As an extension of this work, Lori is investigating teacher design thinking and practices.

Associate Professor Shirley Agostinho works in the School of Education at the University of Wollongong. Her research is devoted to designing effective learning environments and encompasses the dual perspectives of examining how teachers can be supported to design high quality learning experiences and how learners can support their own learning through the use of ICT. 


\begin{abstract}
Improving teacher design promises to be a scalable, sustainable approach to building capacity amongst a workforce faced with complex and evolving drivers of change in higher education worldwide. While design has long been recognised as a routine part of teaching, there has been renewed interest in supporting and understanding the design work that teachers do to foster innovation, particularly in technology-enhanced learning, at institutional scale by influencing teachers' practices. Re-framing teaching as design usefully emphasises the creative problem-solving needed to balance pedagogical, logistical and technical considerations within specific educational contexts, tailored to learners' needs. There is potential for this re-framing to build on and advance work in 'learning design' and 'design for learning' that has generated a wide range of practical supports and tools. In this article, we explore, problematise and conceptualise the notion of 'teacher as designer' within the complexity of contemporary higher education through a critical review of existing empirical and conceptual work internationally. We offer insights into the current state of knowledge about teacher design in higher education, highlight gaps and possibilities, offer a new conceptualisation drawing on practice theory, and set out propositions to provoke further debate about teacher design as a vehicle for sustainable innovation in higher education.
\end{abstract}

\title{
Introduction
}

Higher education drives societal and economic advancement by producing high quality graduates through high quality teaching. But with higher education teaching under an evolving range of pressures, the sector's capacity to deliver these benefits into the future is at risk. These pressures include a diversifying student base, greater internationalisation, higher expectations from employers, more competition from rival providers, and increasing reliance on digital technologies to offer flexibility and achieve teaching efficiencies (Goodyear, 2015). The result is a complexity of forces that is placing demands on a sector in which research has often been emphasised over teaching. With investment in teaching and learning under scrutiny in many countries (Universities Australia, 2015), it is time to re-think the challenge of improving quality. 
Focusing attention on effective design has been proposed as a key strategy for improving the quality of higher education teaching (Goodyear, 2015; Laurillard, 2012). Growing expectations of innovation, particularly through technology-enhanced learning, has provided much of the stimulus for this new focus. Goodyear (2012) argues that institutions can respond by becoming more 'design-savvy' and building design capacity throughout the organisation. Given the significant proportion of the higher education workforce directly engaged in teaching, building design capacity in teachers ${ }^{1}$ offers opportunities for large scale, sustainable change. Targeting the staff who are directly responsible for teaching acknowledges them as agents of innovation and change. These 'front-line' educators play a major role in enacting new policies and procedures, implementing new approaches and adopting new tools, and influencing students' adoption of new learning technologies (Ertmer, 2005; Margaryan, Littlejohn \& Vojt, 2011). Teaching staff across all subject disciplines play a role in design, which offers reach institution-wide, thereby expanding the scale of possible change. And, investing in capacity building of staff seeks to effect long-term change, enhancing the potential for sustainability into the future. Capacity building also offers a valuable complement to other responses that might focus on improving productivity and reshaping internal structures and policies, which would also support effective design.

Effective design is critical to high quality learning outcomes. Approaches to teaching have been shown to influence student learning and student outcomes, and vice versa (Baeten et al., 2010; Trigwell, Prosser \& Waterhouse, 1999; Postareff \& LindblomYlänne, 2008). It follows then that teachers' approaches to design and their design choices are also integral to this set of inter-relations. The idea that design is inherently aligned to a teacher's role in creating an environment that promotes learning is not new (see for example, Dinham, 1989; Stark, 2000), but the increasing expectations of teachers to design for technology-enhanced learning have led to growing calls for a more widespread adoption of the concept of 'teaching as design' with a view to improving the quality of teaching and fostering innovation (Goodyear, 2015; Koh, Chai, Wong \& Hong, 2015; Laurillard, 2012). With this renewed interest, comes the

\footnotetext{
${ }^{1}$ We use 'teachers' throughout this article in a generic sense to refer to staff members in higher education institutions responsible for teaching across all subject disciplines, whether teaching is their main role or forms part of their responsibilities.
} 
need to better understand what we mean by teacher design so that we can pursue initiatives to develop and support it.

Design is already a routine part of a teacher's work. Teacher design work most obviously entails the planning and preparation every teacher does before the beginning of the academic session in deciding what topics to cover, how content should be presented, what learning activities students should engage in, and how learning should be assessed. But teacher design goes beyond this to include problematising learning opportunities, building in choice and challenge for students, anticipating student needs and responses, constantly seeking to improve, and working with contextual constraints and influences to achieve teaching and learning goals. Designing for learning also encompasses gathering feedback, making adaptive changes while teaching, implementing improvements to future iterations of the course, and customising designs to suit new situations. This design work is shaped by a host of enablers and constraints that depend on the specific context, ranging from learner characteristics and teaching expertise through to institutional rules and disciplinary norms. And depending on the type of course, teachers may have significant autonomy in design or may need to meet the requirements of accreditation. Conceptualising 'teaching as design' offers a holistic conception of these activities that moves well beyond the more readily observable work of teaching classes or grading assignments.

A shift towards thinking of teaching as design is not without challenges. At present, the empirical evidence about teacher design is emergent, with significant further work needed to build a comprehensive knowledge base. Further, the best-known conceptualisations of teaching and learning in higher education are yet to incorporate detail about teacher design activities (e.g. Biggs, 2001; Entwistle et al, 2001; Laurillard, 2002). So, for many teachers and administrators in higher education, the notion of design will be unfamiliar, particularly in the context of teaching. Further still, the practical problems of adoption and change in higher education will need to be tackled. The adoption of new practices depends on favourable conditions, and sector-wide changes to teaching have been elusive. In short, 'teaching as design' requires a major shift in the ways teaching is both conceptualised and practiced, with the ultimate goal of activating and building teachers' capacity to design and 
implement the highest quality learning experiences for students. This can only occur if we can understand the fundamental processes of teacher design to equip us with evidence of how best to engage with and support teachers' work.

The aim of this paper is to stimulate thinking and discussion about teacher design as a strategy for sustainable, large-scale improvements in higher education teaching and learning. We begin by synthesising and critiquing the emergent body of research on teacher design as it has developed in educational technology and related work. In doing so we identify some gaps that suggest fruitful lines of inquiry towards building a more comprehensive knowledge base. We then outline a new approach to conceptualising teacher design, drawing on existing research findings, which can be advanced through the notion of practice architectures. Finally, we offer some propositions about furthering work in this area.

\section{Teacher design in higher education}

Over the past two decades conceptual and practical developments have sought to conceptualise teachers' design work, investigate the practices that comprise it and develop supports that will improve it. This body of work encompassing 'design for learning, 'learning design' and 'pedagogical patterns' has focused mainly on developing supports and tools for technology-enhanced learning, with a minor line of research on the design practices and processes currently employed by teachers. Efforts to date have been underpinned by three key ideas:

1. Designs can be represented in systematic ways that formally document their pedagogic features.

2. Representations can be shared for other teachers to adopt and adapt to their contexts, to improve and share again.

3. Technology tools can be developed to support creation, representation, sharing, and adaptation of designs.

The result is a set of related, but sometimes disparate activities founded on the premise that representing effective teaching and learning designs in a systematic way will support teachers' design practices by encouraging adaptive reuse, which in turn will ultimately lead to improved practice. 
A diverse array of projects and studies has contributed to refinement of the idea over time. From a recent effort to trace more than a decade of developments in learning design (Dalziel et al., 2016), it is possible to identify three main areas of inquiry:

- strategies for representing learning designs to teachers in forms that promote sharing and adaptive reuse (e.g., Agostinho, 2011; McAndrew \& Goodyear, 2013; Mor, Mellar, Warburton \& Winters, 2014);

- technical specifications for interoperable machine-readable descriptions of designs (e.g., Botturi, 2006; Koper \& Olivier, 2004); and

- tools and strategies that provide guidance for teachers' design processes (e.g., Conole \& Culver, 2010; Hernández-Leo, Asensio-Pérez, Derntl, Prieto \& Chacón, 2014; Laurillard et al, 2013; Masterman \& Manton, 2011) and studies on the use and effectiveness of those tools and strategies (e.g., Asensio-Pérez, et al, 2017; Bennett, Lockyer \& Agostinho, 2004).

The diversity of activities to date reflects how differently the central notion of 'teacher as designer' has been interpreted and pursued. Differences in underpinning assumptions about the role of the teacher and the nature of educational design within varied traditions of face-to-face, blended, distance and open learning have led to different interpretations of the problem at hand. For example, technically oriented projects have focused on solutions for efficient delivery, whereas pedagogically oriented projects have focused on professional development to build design expertise among teaching staff. A tendency for the work on specifications to be conducted separately to the work directly with teachers has resulted in a separation of the technical and pedagogical agendas, despite efforts within some projects and networks to bridge this gap.

A relatively minor strand of research has focused on investigating existing teacher design practices in higher education (Goodyear, 2012). Findings from this body of work reveal the following key findings:

- Higher education teachers across disciplines have a level of autonomy to make design decisions, often with individual responsibility for a unit within a larger course team (Bennett et al., 2011). The levels of autonomy vary depending on accreditation or professional requirements, and institutional policies and procedures. 
- There are broad qualitative differences in the conceptions teachers have of learning and learning technologies, and these are associated with more/less effective approaches to teaching and design (Ellis, Hughes, Weyers \& Riding, 2009; Postareff \& Lindblom-Ylänne, 2008).

- Teachers' design decisions are influenced by disciplinary differences in course goals, student characteristics and teaching practices, with teachers' perceptions of the student experience of their designs a major factor (Bennett, Agostinho \& Lockyer, 2015; Goodyear \& Markauskaite, 2009; Stark, 2000).

- Teachers' design processes reflect key characteristics of design more generally but are not as systematic and complete as those of specialist educational designers (Bennett, Agostinho \& Lockyer, 2017; Hoogveld, Paas, Jochems \& Van Merriënboer, 2002).

- Teachers source their design ideas from colleagues, the literature, workshops/seminars, conferences, institutional support services (including specialist designers), and enrolment in formal postgraduate study (Agostinho, Lockyer \& Bennett, 2018).

Together, these findings provide a foundation for research in this nascent area of teacher design, but there is still much to discover about current design practices in higher education.

Further work on this line of research can draw on complementary educational design research in different contexts. This could include the long tradition of research into how school teachers plan and prepare (e.g., Clark \& Yinger, 1977; Elbaz, 1991; McCutcheon, 1980), which has recently extended to more contemporary design practices (e.g., Boschman, McKenney, \& Voogt, 2014; Kali, McKenney \& Sagy, 2015). School teaching has many of the same characteristics as teaching in higher education, however differences in the ways school teachers are prepared and the dynamics of schools will be less transferable. Also relevant is the well established research into the work of specialist educational designers (e.g., Ertmer, Parisio \& Wardak, 2013; Gibbons, 2014). Specialist educational design work is highly varied, situated both within and independent of educational institutions, and is usually distinct from actual teaching. In higher education institutions, specialist educational designers play an important role in supporting teaching staff, in conjunction with technical and 
media services. While specialist designers occupy a quite different role to a teacher as designer, exploration of the commonalities and differences will stimulate thinking about the key characteristics of teaching as design. Further theoretical and empirical work will reveal the extent to which such differences give rise to differences in design practice.

Wider still is the work on design more generally, stemming from research into engineering, architecture, programming, industrial design and graphic design. This draws in research on processes and cultures, and highlights differences between novice and expert designers and approaches to design training (e.g., Cross, 2006; Goldschmidt \& Weil, 1998; Lawson, 2004). This research could inform us about the extent to which teachers' design work reflects the distinctive characteristics of design gleaned from other fields (see Razzouk \& Shute, 2012 for a recent review). The resurgence of interest in 'design thinking' as a basis for school education and for innovation generally (e.g., Dorst, 2011; Koh, 2015), may also be worth pursuing to inform our conceptualisation and realisation of teaching as design. At present, however, these ideas are contested and yet to be rigorously tested.

To summarise, research and development work in teacher design in higher education to date has advanced practical and technical solutions seeking to effect change, outpacing progress in understanding the nature of teacher design itself. To date, the field has focused on what might be done to support teacher design through a diversity of projects and approaches. This work has been underpinned by varied interpretations of what teachers do, and should do, when they design. A diversity of views is not unexpected in an emerging field, nor is it inherently problematic. It does, however, invite a reconciliation of various interpretations of teacher design that could contribute significantly to the maturation of this research and development agenda. Recently a network of researchers made a first attempt to map these understandings and negotiate a shared set of principles to inform further work (Dalziel et al., 2016). This development signals that it is timely to consider what more could be done and to identify gaps and possibilities for advancing the field.

\section{Gaps and possibilities}


Of the several 'big picture' strategies that could advance the field, a critical step would be to more closely examine the interpretations of teacher design that underpin the research and development initiatives in learning design to date. This small but growing body of work into what teachers do when designing for student learning (Goodyear, 2012) provides a starting point for further empirical and theoretical work. The aim would be to build a more comprehensive understanding of current teacher design practice, across a range of disciplinary and institutional contexts, and encompassing ways of working with other teaching and support staff. To do this we will need empirical research that includes teachers at various stages of working with technology-enhanced learning, to draw on the experiences of those working at the 'cutting edge' through to more conventional applications. This diversity would capture both the routine and the aspirational. This new knowledge would form the basis of an approach focused on adaptation of existing practice in ways that build teacher design capacity.

To support this research effort, we are in need of conceptualisations of teacher design practice that can be further explored empirically to better understand the processes, influences and decisions involved in designing for learning and teaching. Stronger theorisation would help to guide research that can comprehensively address the various aspects of teacher design, from the personal characteristics of teachers that influence design decisions, through to the influence of the institutional and professional context, amongst others. Using this framework as a structure would then enable exploration of variations, for example, between disciplines, and across the higher education sector.

A more robust empirical and theoretical base is an important foundation for advancing research and development in this area. This work involves identifying key research questions to lead empirical and development work that will advance understanding in the field enabling theory to be tested and refined. Researchers would still pursue a range of questions from a range of perspectives, but with a greater awareness of and connection to others' work on teacher design and related work outside the immediate field. A knowledge base of studies that build on and connect to one other will address fragmentation in the field, and also provide an evidence base to support teacher design initiatives, particularly the development of technology-based tools. 


\section{Conceptualising teacher design}

Teacher design involves individual cognitive acts of design thinking. These acts occur within a social context, and it is this social context that shapes both the design process and the design outcome. The immediate focus may be, for example, the design of a unit/subject within a course of study. The teacher designs the unit to foster particular kinds of student responses, for example to encourage engagement with a resource, an interaction with peers, or completion of an assessment. This design work is influenced by an array of factors, including the anticipated needs and capabilities of the students, the teacher's beliefs about learning and teaching, and the norms of the institution and discipline (Lockyer, Agostinho, Bennett, 2017). The design process is iterative, multilayered and sustained, extending over the period before, while and after a unit is taught, demonstrating that is it much more than planning and preparation (Bennett, et al 2017). Design is not necessarily a 'one-off' process in that redesign of existing units is a major part of teacher design work. Even a new unit may not be entirely new, being perhaps based on adaptations of previous designs. Designing a unit also shapes the teacher as designer, building their stock of design experience and, potentially, their teaching repertoires. Furthermore, teacher design in higher education is just one of the multiple responsibilities that comprise the 'academic ecosystem' as research, governance, and teaching responsibilities shape and inform the social and psychological tools that support design. Teaching staff face multiple demands and shifting priorities, shaped by institutional and disciplinary contexts, and prior experiences.

This brief account of teacher design suggests a need to account for the ways individuals work within their contexts, shaped by present and past experiences. Goodyear and Dimitriadis (2013) offer a preliminary proposition that a theory of "design for learning" should focus on:

- Who is doing the designing? Who is doing the learning? Who else is involved?

- Why is the design work being done? Why are the learners doing what they do?

- What is designed? What is learned?

- How is the design work undertaken? How does the learning activity occur? 
This useful starting point highlights the need for teacher design to be conceptualised jointly with student learning. Laurillard's (2012) work connecting pedagogical patterns with learning through acquisition, inquiry, discussion, practice and collaboration is an important contribution to advancing this agenda. A further avenue is to begin to explore the wider social contexts in which teaching and learning occurs that can "account for any significant relationships between the entities (people, places, artefacts, etc.) implicated in the design and the learning activities" (Goodyear and Dimitriadis, p5).

Practice theory offers a promising approach to achieve this. In simple terms, 'practice theory' seeks to explain what people do when engaging in a social activity and why. 'Practices' are situated in particular contexts, involving particular people, in particular locations, at particular times. But similar practices can exist in different locations. Practices are shaped by traditions, but also evolve in response to change. We can, for example, view teaching through a practice theory lens as a way to conceptualise what teachers do and why, located in their particular contexts (eg. Boud, Dawson, Bearman, Bennett, Joughin and Molloy, 2018).

There are many practice theories (Kemmis, 2009), but for the purpose of this discussion we focus on the theories of practice architectures and ecologies of practices (Kemmis et al., 2014) as a theoretical lens to conceptualise teacher design. A practice is a human social activity that has characteristic forms of understandings (sayings), actions (doings) and ways people relate to one another and the world (relatings). The essence of a practice is in a practitioner's answers to the questions: "What am I doing and why?" and "How is it done here?". For teachers, this becomes: "What am I designing and why?" and "How is design done here?". Students might also be considered 'practitioners' of their own learning, with the equivalent questions: "What am I learning and why?" and "How is learning done here?". In the social space of a unit of study, the answers to these questions will be intimately related.

Practices are social phenomena that happen within a site or sites, and that exist in physical space-time and in history. Practices may be located in multiple sites, and one practice can be a site for other practices (Schatzki, 2002). Units, courses, programs and institutions are inter-related sites for teaching practices, and individual teachers 
and students will engage in multiple sites. The ways a practice is enacted across different but related sites may vary but will also reflect common practice traditions. The theory of practice architectures contends that a practice is enabled or constrained by three kinds of arrangements that are always present in a site: 1) cultural-discursive arrangements (discourses that shape what teachers and students think and say about their practice); 2) material-economic arrangements (arrangements in space and time that shape what teachers and students can do in their practice); and 3) social-political arrangements (social relationships, such as roles, that shape how teachers and students relate to one another in their practice). The theory of ecologies of practices asserts that practices sometimes form relationships of interdependence with other practices, creating a complex web of practices in which one practice becomes a practice architecture for another practice (Mahon, Francisco, \& Kemmis, 2017). For example, a teacher's design practice provides a practice architecture for student learning in a unit, while a teacher's broader academic role provides a practice architecture for their design practice, and a constellation of teaching and learning practices within an institution provide an array of practice architectures for teacher design and student learning practices. Changes in practice occur when practitioners can and do change what they do according to their own goals and aspirations, and through changes to the arrangements (practice architectures) in the site that support existing practices.

Thus, the theory of practice architectures, including the theory of ecologies of practices, provides a strong conceptual and analytical frame to examine teacher design within the context of academic professional practice and as shaped by disciplinary and institutional norms. It offers a theoretical resource of describing and interpreting the social world, an analytical resource to identify empirical connections between practices and arrangements, and also a transformational resource to discern pathways for change to occur (Mahon, Francisco, \& Kemmis, 2017). This last feature is important to ambitions to frame teaching as design and to build teachers' design capacity through changes to current teaching practices. This element of the theory helps to conceptualise what changes to current teaching would be needed for innovations to be sustained. Change in higher education teaching, particularly in terms of technology-enhanced learning, has been notoriously difficult to effect and arguably miscast as resistance (Blin \& Munro, 2008). A practice theory perspective offers a framing to explore the nature of practices, with their underlying logics and 
relations, in ways that could inform carefully considered change initiatives. Application of these practice theories offers a further opportunity to critique and extend this theoretical lens through empirical studies that investigate how innovation through teacher design might be supported for individuals and within institutions.

\section{Propositions}

To conclude, we offer some propositions for research and development in teacher design that may help to advance the field in ways that will ultimately make a positive difference to practice. Our hope is that these will provoke further debate about the directions the field might take to move it beyond niche research studies and innovative but transient projects.

We propose that teacher design will make a difference if:

\section{1. ... design is seen as integral to and routine in higher education teaching.}

This requires a commitment to understanding teacher design practice as currently it is, as well as what it could and should be, as a basis for supporting shifts in practice.

Current findings from learning design research suggest that support tools and initiatives should align with the lifecycle of teacher design that extends beyond the confines of a single unit and teaching session. This would develop teacher design as cumulative and developmental, whereby 'innovations' are integrated and become routine. The ambition here is that teacher design is 'surfaced', becoming recognised and articulated. This would allow teachers to discuss and share design as unquestionably part of their work, and to develop the kind of heuristics to guide their processes and decision-making that are a feature of other design work (Ertmer, et al., 2008; Razzouk \& Shute, 2012). This will move us towards truly conceptualising 'teaching as design'.

\section{2. ...research translation becomes a priority.}

Ultimately, as understanding of teacher design becomes more established, a higher priority can be placed on research translation. This requires looking for new ways to engage in research and dissemination that move beyond academic approaches. This may, for example, include engaging with practitioners as co-researchers who jointly interpret findings about their practices and co-create support tools and initiatives. This 
approach would extend exploration of key questions in teacher design from a practitioner's perspective, for example about effective forms of design representation and approaches to sharing and adapting designs. Further, there is potential to consider involving learners more as designers of their learning environments, at least in codesign where possible, but also to support self-directed or personalised design of learning. Some of this may involve turning learning design tools over to learners.

\section{3. ...professional learning approaches adapt to build design capacity.}

Learning about design is an ongoing process of professional learning in situ, embedded in the practice of 'doing design'. This suggests a fundamental shift away from current approaches to teacher professional development in higher education, which occurs mainly through individual support, pre-planned workshops, teacher-led projects or internally funded initiatives. An alternative model would be one that is characterised by continuous development, integrates social support amongst teachers, is teacher led/driven, adapts to and is able to influence institutional arrangements, and recognises teaching with the broader ecosystem of academic practice. This model would allow teachers to have agency in determining their own development goals and needs, rather than be limited by the pre-planned/pre-determined professional development that an institution assumes teachers need. It is an approach that considers the teacher as a professional who can develop themselves rather than an employee who needs to be trained. A rich vein of research on workplace learning (e.g., Billet, 2002; Littlejohn, Milligan \& Margarayn, 2011) could inform this shift.

\section{4. ...institutional arrangements are open to change.}

In line with practice theory, changes to arrangements within higher education institutions are likely to be needed to support changes in teaching practice. Initially, there may be work to do in developing understanding amongst institutional leaders and policy-makers of the contribution of teacher design to improving the quality of education. One strategy is to engage teaching and learning leaders in the process of research translation such that findings are relevant to those with delegated authority and responsibility for resource allocation within institutions. If internal barriers to teacher design are not mitigated or removed, and enablers are not enhanced or introduced, there is little prospect that sustainable change will occur. Beyond eliciting support from leaders, there is a great deal we do not yet understand about how to 
effect lasting organisational change through changing practices within higher education institutions. Teacher design could provide a focus for new inquiries pursuing these questions.

\section{5. ...we acknowledge and appreciate the limits of teacher design.}

Finally, we must be clear about the limits of teacher design. As practice theory highlights, teacher design is only one component of the broader teaching and learning ecosystem. Effective design cannot guarantee high quality experiences and outcomes for every learner. While a teacher may design a task intended to encourage deep engagement, the response of a student is influenced by an array of factors far beyond the teacher's sphere of influence (Baeten et al, 2010; Biggs, 2001). We must acknowledge and understand these limitations when promoting teacher design. Greater support for teacher design will not address all that challenges higher education, but it can play an important role in adaptation to change that will maintain and build teaching excellence.

\section{Summary}

In this article, we considered the challenge of effecting change within the complex environment of higher education by considering the concept of 'teaching as design'. In doing so we have provided a critical overview of the range of prior research and development work that has attempted to foster change in teaching primarily through the notion of 'learning design' or 'design for learning'. We argue that, while this body of work provides an understanding of initiatives that have advanced the field, there remain important gaps in our understanding of higher education teachers' design practices that must be investigated to develop foundational knowledge from which to progress widespread practice change. We suggest conceptualising teacher design through a lens of practice theory will help to more holistically understand the design work of higher education teachers, put it in the frame of their broader academic responsibilities and allow for understanding of the interrelationship between teacher design and student learning practice. Finally, we offer five propositions to stimulate discussion about the opportunities for research and development about teacher design with an ultimate goal of effecting sustainable innovation in higher education.

\section{Acknowledgements}


There are no conflicts of interest to report.

\section{References}

Agostinho, S. (2011). The use of a visual learning design representation to support the design process of teaching in higher education. Australasian Journal of Educational Technology, 27(6), 961-978.

Agostinho, S., Lockyer, L., \& Bennett, S. (2018). Identifying the characteristics of support Australian university teachers use in their design work: Implications for the learning design field. Australasian Journal of Educational Technology, 34(2), 1-14. doi: https://doi.org/10.14742/ajet.3776

Asensio-Pérez, J. I., Dimitriadis, Y., Pozzi, F., Hernández-Leo, D., Prieto, L. P., Persico, D., \& Villagrá-Sobrino, S. L. (2017). Towards teaching as design: exploring the interplay between full-lifecycle learning design tooling and teacher professional development. Computers \& Education, 114, 92-116.

Baeten, M., Kyndt, E., Struyven, K., \& Dochy, F. (2010). Using student-centred learning environments to stimulate deep approaches to learning: Factors encouraging or discouraging their effectiveness. Educational Research Review, 5(3), 243-260.

Bennett, S., Agostinho, S., \& Lockyer, L. (2015). Technology tools to support learning design: Implications derived from an investigation of university teachers' design practices. Computers and Education, 81, 211-220.

Bennett, S., Agostinho, S., \& Lockyer, L. (2017). The process of designing for learning: Understanding university teachers' design work. Educational Technology Research \& Development, 65, 125-145.

Bennett, S. Agostinho, S., \& Lockyer, L. (2004). Investigating how learning designs can be used as a framework to incorporate learning objects. In R. Atkinson, C. McBeath, D. Jonas-Dwyer \& R. Phillips (Eds.), Proceedings of the Annual Conference of the Australasian Society for Computers in Learning in Tertiary Education (pp. 116-122). Perth, WA: ASCILITE. 
Bennett, S., Thomas, L., Agostinho, S., Lockyer, L., Jones, J. \& Harper, B. (2011). Understanding the design context for Australian university teachers: implications for the future of learning design. Learning, Media and Technology, 36 (2), 151-167.

Biggs, J. (2001). Enhancing learning: A matter of style or approach. In R. Sternberg, \& L. Zhang (Eds.), Perspectives on thinking, learning, and cognitive styles (pp. 73102). Mahwah, NJ: Lawrence Erlbaum.

Billett, S. (2002). Workplace Pedagogic Practices: Co-participation and Learning. British Journal of Educational Studies, 50(4), 457-481. https://doi.org/10.1111/14678527.t01-2-00214

Blin, F., \& Munro, M. (2008). Why hasn't technology disrupted academics' teaching practices? Understanding resistance to change through the lens of activity theory. Computers \& Education, 50(2), 475-490.

https://doi.org/10.1016/j.compedu.2007.09.017

Botturi, L. (2006). E 2 ML: A visual language for the design of instruction. Educational Technology Research and Development, 54(3), 265-293.

Boud, D., Dawson, P., Bearman, M., Bennett, S., Joughin, J., \& Molloy, E. (2018). Reframing assessment research: through a practice perspective. Studies in Higher Education, 43(7), 1107-1118. doi: 10.1080/03075079.2016.1202913.

Conole, G., \& Culver, J. (2010). The design of Cloudworks: Applying social networking practice to foster the exchange of learning and teaching ideas and designs. Computers \& Education, 54(3), 679-692.

Cross, N (2006) Designerly ways of knowing. Springer-Verlag, London

Dalziel, J., Conole, G., Wills, S., Walker, S., Bennett, S., Dobozy, E., Cameron, L., Badilescu-Buga, E., \& Bower, M. (2016). The Larnaca Declaration on Learning 
Design. Journal of Interactive Media in Education, 2016(1): 7, pp. 1-24, DOI: http://dx.doi.org/10.5334/jime.407

Dinham, S. M. (1989). Teaching as design: theory, research and implications for design teaching. Design Studies, 10(2), 80-88. https://doi.org/10.1016/0142694X(89)90040-9

Dorst, K. (2011). The core of 'design thinking' and its application. Design Studies, 32(6), 521-532. https://doi.org/10.1016/j.destud.2011.07.006

Ellis, R. A., Hughes, J., Weyers, M., \& Riding, P. (2009). University teacher approaches to design and teaching and concepts of learning technologies. Teaching and Teacher Education, 25(1), 109-117. https://doi.org/10.1016/j.tate.2008.06.010

Entwistle, N., McCune, V., \& Walker, P. (2001). Conceptions, styles, and approaches within higher education. In R. Sternberg \& L. Zhang (Eds.), Perspectives on thinking, learning, and cognitive styles (pp. 103-136). Mahwah, NJ: Lawrence Erlbaum.

Ertmer, P. A. (2005). Teacher pedagogical beliefs: The final frontier in our quest for technology integration? Educational Technology Research and Development, 53(4), 25-39. https://doi.org/10.1007/BF02504683

Ertmer, P. A., Parisio, M. L., \& Wardak, D. (2013). The practice of educational/instructional design. In Luckin, R., Puntambekar, S., Goodyear, P., Grabowski, B. L., Underwood, J., \& Winters, N. (Eds.). (2013). Handbook of design in educational technology. (pp. 5-19). New York: Routledge.

Ertmer, P. A., Stepich, D. A., York, C. S., Stickman, A., Wu, X. L., Zurek, S., \& Goktas, Y. (2008). How instructional design experts use knowledge and experience to solve ill-structured problems. Performance Improvement Quarterly, 21(1), 17-42.

Gibbons, A. S. (2014). Eight views of instructional design and what they should mean to instructional designers. In B. Hokanson \& A. Gibbons (Eds.), Design in Educational Technology (pp. 15-36). Cham: Springer International Publishing. 
Goldschmidt, G., \& Weil, M. (1998). Contents and structure in design reasoning. Design Issues, 14(3), 85. https://doi.org/10.2307/1511899

Goodyear, P. (2015). Teaching as design. HERDSA Review of Higher Education, 2, 27-50.

Goodyear, P., \& Dimitriadis, Y. (2013). In medias res: reframing design for learning. Research in Learning Technology, 21(suppl. 1).

Goodyear, P. \& Markauskaite, L. (2009) Teachers' design knowledge, epistemic fluency and reflections on students' experiences, in The Student Experience, Proceedings of the 32nd HERDSA Annual Conference, Darwin, 6-9 July 2009: pp $154-162$.

Hernández-Leo, D., Asensio-Pérez, J. I., Derntl, M., Prieto, L. P., \& Chacón, J. (2014). ILDE: Community environment for conceptualizing, authoring and deploying learning activities. In Open learning and teaching in educational communities (pp. 490-493). New York: Springer.

Hoogveld, A. W., Paas, F., Jochems, W. M., \& Van Merriënboer, J. J. (2002). Exploring teachers' instructional design practices from a systems design perspective. Instructional Science, 30(4), 291-305.

Kali, Y., McKenney, S., \& Sagy, O. (2015). Teachers as designers of technology enhanced learning. Instructional Science. https://doi.org/10.1007/s11251-014-9343-4

Kemmis, S. (2009). What Is Professional Practice? Recognising and respecting diversity in understandings of practice. In C. Kanes (Ed.), Elaborating professionalism (pp. 139-165). Dordrecht: Springer Netherlands. https://doi.org/10.1007/978-90-481-2605-7_8

Kemmis, S., Wilkinson, J., Edwards-Groves, C., Hardy, I., Grootenboer, P. \& Bristol, L. (2014). Changing education, changing practices. Singapore: Springer Education. 
Koper, R., \& Olivier, B. (2004). Representing the learning design of units of learning. Journal of Educational Technology \& Society, 7(3).

Koh, J. H. L., Chai, C. S., Wong, B., \& Hong, H.-Y. (2015). Design Thinking for Education. Singapore: Springer Singapore.

Lawson, B. (2004). Schemata, gambits and precedent: some factors in design expertise. Design Studies, 25(5), 443-457.

Laurillard, D. (2002). Rethinking university teaching. New York: Routledge.

Laurillard, D. (2013). Teaching as a design science. New York: Routledge.

Laurillard, D., Charlton, P., Craft, B., Dimakopoulos, D., Ljubojevic, D, Magoulas, G., Masterman, E., Pujadas, R, Whitley, E. \& Whittlestone, K. (2013). A constructionist learning environment for teachers to model learning designs. Journal of Computer Assisted Learning, 29(1), 15-30.

Littlejohn, A., Milligan, C., \& Margarayn, A. (2011). Collective learning in the workplace: Important knowledge sharing behaviours. International Journal of Advanced Corporate Learning (IJAC), 4(4), 26-31.

Lockyer, L., Agostinho, S., \& Bennett, S. (2016). Design for e-learning. In C. Haythornthwaite, R. Andrews, J. Fransman \& E. Meyers (Eds.), The SAGE handbook of e-learning research (pp. 336-353). London: Sage.

Mahon, K., Francisco, S. \& Kemmis, S. (Eds.), (2017). Exploring education and professional practice - Through the lens of practice architectures. Singapore: Springer.

Masterman, E., \& Manton, M. (2011). Teachers' perspectives on digital tools for pedagogic planning and design. Technology, Pedagogy and Education, 20(2), 227246. 
Margaryan, A., Littlejohn, A., \& Vojt, G. (2011). Are digital natives a myth or reality? University students' use of digital technologies. Computers \& Education, 56(2), 429-440. https://doi.org/10.1016/j.compedu.2010.09.004

McAndrew, P., \& Goodyear, P. (2013). Representing practitioner experiences through learning designs and patterns. In H. Beetham \& R. Sharpe (eds), Rethinking pedagogy for a digital age: Designing for 21 st century learning (pp. 133-144). New York: Routledge.

Mor, Y., Mellar, H., Warburton, S., \& Winters, N. (eds) (2014). Practical design patterns for teaching and learning with technology. Rotterdam: Sense Publishers.

Postareff, L., \& Lindblom-Ylänne, S. (2008). Variation in teachers' descriptions of teaching: Broadening the understanding of teaching in higher education. Learning and Instruction, 18(2), 109-120. https://doi.org/10.1016/j.learninstruc.2007.01.008

Razzouk, R., \& Shute, V. (2012). What is design thinking and why is it important? Review of Educational Research, 82(3), 330-348.

Schatzki (2002). The site of the social: A philosophical account of the constitution of social life and change. University Park: The Pennsylvania State University Press,

Stark, J. S. (2000). Planning introductory college courses: Content, context and form. Instructional Science, 28(5), 413-438.

Trigwell, K., Prosser, M., \& Waterhouse, F. (1999). Relations between teachers' approaches to teaching and students' approaches to learning. Higher Education, 37(1), 57-70.

Universities Australia. (2015). Keep it clever policy statement 2016. Retrieved from https://www.universitiesaustralia.edu.au/ArticleDocuments/209/Keep\%20it\%20Cleve r\%20Policy\%20Statement\%202016.pdf.aspx 